\title{
Genetic Annotation Index
}

National Cancer Institute

\section{Source}

National Cancer Institute. Genetic Annotation Index. NCI Thesaurus. Code C15940.

A listing of genetic variations in genes important to cancer 